\title{
ANALISIS KENDALA PEMBELAJARAN MATEMATIKA BERBASIS ONLINE (E-LEARNING) PADA MASA PANDEMI COVID-19
}

\author{
Soffiani Tri Putri', Dadang Rahman Munandar ${ }^{2}$ \\ 1,2 Universitas Singaperbangsa Karawang \\ soffiaputri99@gmail.com
}

\begin{abstract}
Mathematics is an essential subject to study so that it must be pursued in its implementation and possible. The existence of the covid-19 pandemic requires all learning activities to be carried out online. But in practice, online learning experiences several obstacles, especially in learning mathematics. For this reason, the purpose of this study is to describe the constraints in the online-based mathematics learning process (e-learning). This study uses a descriptive method with a qualitative approach. The subjects in this study were students of class VIII SMPN 1 Rawamerta. The research instrument was in the form of a student response questionnaire regarding online-based learning (e-learning), which consisted of seven closed questions and four open questions. Data collection was carried out by distributing the google link form to the student response questionnaire to the research subject. Data analysis was carried out descriptively by testing the validity of the data through triangulation techniques. The results showed that students' obstacles in online-based mathematics learning (e-learning) were technical and personal constraints. Technical constraints are in the form of an unstable internet network, internet quota, and teacher explanations that are not heard clearly. In contrast, unique constraints are the lack of students in understanding the learning material and feeling lazy to take online-based mathematics learning.
\end{abstract}

Keywords: Learning Obstacle, Online-Based Mathematics Learning(E-Learning), Covid-19

ABSTRAK Matematika merupakan mata pelajaran yang penting untuk dipelajari, sehingga dalam pelaksanaannya harus diupayakan dengan sebaik mungkin. Adanya pandemi covid19 mengharuskan semua kegiatan pembelajaran dilakukan secara online. namun dalam pelaksanaannya, pembelajaran online tersebut mengalami sejumlah kendala terutama dalam pembelajaran matematika. Untuk itu, tujuan dari penelitian ini yaitu mendeskripsikan kendala dalam proses pembelajaran matematika berbasis online (e-learning). Penelitian ini menggunakan metode deskriptif dengan pendekatan kualitatif. Subjek dalam penelitian ini yaitu siswa kelas VIII SMPN 1 Rawamerta. Instrumen penelitian berupa angket respon siswa mengenai keterlaksanaan pembelajaran berbasis online (e-learning) yang terdiri dari tujuh pertanyaan tertutup dan empat pertanyaan terbuka. Pengumpulan data dilakukan dengan penyebaran link google form angket respon siswa kepada subjek penelitian. Analisis data dilakukan secara deskriptif, dengan pengujian keabsahan data dilakukan melalui teknik triangulasi. Hasil penelitian menunjukan bahwa secara umum kendala yang dialami siswa dalam pembelajaran matematika berbasis online (e-learning) yaitu kendala teknis dan kendala personal. Kendala teknis berupa jaringan internet yang tidak stabil, kuota internet, serta penjelasan guru yang kurang terdengar jelas, sedangkan kendala personal yaitu kurangnya siswa dalam memahami materi pembelajaran, serta rasa malas untuk mengikuti pembelajaran matematika berbasis online.

Kata-kata Kunci : Kendala Pembelajaran, Pembelajaran Matematika online, Covid-19 


\section{PENDAHULUAN}

Matematika merupakan mata pelajaran wajib yang harus dipelajari siswa pada setiap jenjang pendidikan, baik pendidikan dasar maupun menengah (Utami \& Cahyono, 2020). Hal tersebut didasari oleh beberapa alasan diantaranya yaitu peran matematika sebagai kemampuan dasar (basic competence) yang harus dimiliki oleh setiap orang (Warmi et al., 2020). Kemampuan dasar tersebut dapat membantu manusia dalam menyelesaikan masalahnya dalam kehidupan sehari-hari. Karena tanpa kita sadari, setiap aspek kehidupan manusia selalu berkaitan dengan konsep matematika. Selain itu, matematika juga bersifat universal, dengan artian bahwa matematika memiliki peran penting dalam perkembangan ilmu pengetahuan lainnya (Ningsih \& Nurrahmah, 2016). Pentingnya mempelajari matematika juga didasari alasan bahwa matematika berperan penting dalam mengembangkan potensi yang dimiliki siswa (Lestari et al., 2018). Hal tersebut karena adanya aspek berpikir dan logika dalam matematika yang dapat melatih dan mengembangkan potensi siswa khususnya potensi kognitif, seperti kemampuan berpikir tinggkat tinggi yang mencakup berpikir secara logis, kritis, terstruktur, serta kreatif (Ulfa, 2019). Mengingat pentingnya peran matematika dalam kehidupan, maka pembelajaran matematika harus diupayakan dengan sebaik mungkin.

Pandemi covid-19 yang telah melanda memberikan pengaruh terhadap sektor pendidikan, salah satunya yaitu pembelajaran matematika. Pengaruh tersebut terlihat dari adanya perubahan sistem pembelajaran tatap muka menjadi pembelajaran online (Arcat, 2020), dimana proses pembelajaran dilakukan secara jarak jauh dengan memanfaatkan peran teknologi serta media pembelajaran yang relevan. Pembelajaran secara jarak jauh ini merupakan bagian dari pembelajaran berbasis online (e-learning).

E-learning merupakan pembelajaran yang memanfaatkan bantuan elektronik (Fatmawati, 2019). E-learning memungkinkan guru dan siswa dapat melakukan proses pembelajaran tanpa harus melakukan tatap muka secara langsung. Elearning atau pembelajaran berbasis online ini dianggap menjadi pilihan yang tepat untuk melangsungkan proses pembelajaran pada situasi pandemi, dimana dalam pelaksanaannya pembelajaran dihimbau untuk dilaksanankan di rumah saja demi memutus mata rantai penyebaran covid-19. Disamping itu, pembelajaran online juga sesuai dengan tuntutan pembelajaran abad 21 (abad digital) yang menempatkan teknologi sebagai bagian tidak terpisahkan dengan sistem pembelajaran. Pembelajaran online (e-learning) memungkinkan siswa dan guru dapat melangsungkan kegiatan pembelajaran tanpa harus memerhatikan keterbatasan ruang dan waktu. Sejumlah manfaat yang diperoleh dengan pelaksanaan pembelajaran online (e-learning) diantaranya yaitu pembelajaran menjadi lebih praktis, ekonomis, serta fleksibel dengan hanya memanfaatkan peralatan teknologi serta jaringan internet (Rohmah, 2011). Beberapa aplikasi yang digunakan untuk menunjang pembelajaran online diantaranya yaitu Google Meet, Google Classroom, WhatsApp, Zoom, dan lain sebagainya. 
Pembelajaran online (e-learning) merupakan suatu hal yang terbilang baru bagi sistem pendidikan di Indonesia. Terlebih bagi sekolah - sekolah yang terbiasa menerapkan pembelajaran konvensional, tentunya membutuhkan proses adaptasi lebih dalam mengaplikasikan pembelajaran online tersebut terutama dalam pembelajaran matematika. Tidak semua sekolah pernah melaksanakan sistem pembelajaran online, sehingga dapat dimaklumi jika ditemukan beberapa kendala dalam proses pengaplikasiannya. Hal tersebut sejalan dengan pernyataan dari (Hutauruk \& Sidabutar, 2020) yang menyatakan bahwa masih terdapatnya kendala dalam pelaksanaan pembelajaran berbasis online. Kendala tersebut menjadikan proses pembelajaran menjadi tidak optimal yang mengakibatkan tidak optimalnya pula pemahaman yang dimiliki siswa atas materi yang dipelajari. Hal tersebut menunjukan bahwa sejumlah manfaat yang ditawarkan dalam pembelajaran matematika berbasis online (e-learning) tersebut belum dapat menjanjikan pelakasanaan pembelajaran berjalan dengan baik, terlebih dengan berbagai kendala yang dialami selama proses pembelajaran.

Berdasarkan paparan di atas mengenai pentingnya pembelajaran matematika, serta terdapat permasalahan berkaitan dengan kendala dalam pelaksanaan pembelajaran matematika berbasis online (e-learning), maka perlu dilakukan analisis mengenai keterlaksanaan pembelajaran matematika berbasis online tersebut. Adapun tujuan dari penelitian ini yaitu mendapatkan fakta terkait dengan kesulitan yang dialami siswa dalam melaksanakan pembelajaran matematika berbasis online (e-learning). Keterbaruan dari penelitian ini dengan penelitian sebelumnya terletak pada fokus penelitian. Penelitian terdahulu memfokuskan penelitiannya pada kendala pembelajaran daring pada kalangan mahasiswa, sedangkan penelitian ini memfokuskan pada kendala yang dialami siswa dalam melakukan pembelajaran matematika berbasis online (e-learning). Hasil dari penelitian ini diharapkan dapat dijadikan bahan evaluasi dalam pelaksanaan pembelajaran matematika yang lebih baik lagi.

\section{METODE PENELITIAN}

Penelitian ini menggunakan pendekatan kualitatif dengan metode yang digunakan yaitu deskriptif. Subjek dalam penelitian ini adalah siswa kelas VIII SMP Negeri 1 Rawamerta yang berjumlah 17 orang. Teknik pengumpulan data dilakukan dengan pemberian angket respon siswa mengenai keterlaksanaan pembelajaran matematika berbasis online (e-learning) dengan menggunakan google form. Teknik penyebaran angket dilakukan dengan membagikan link google form pada subjek penelitian untuk kemudian dilakukan analisis. Instrumen penelitian terdiri dari instrumen utama yaitu peneliti sendiri, serta instrumen pendukung berupa angket respon siswa. Angket tersebut berisikan 11 pertanyaan dengan tujuh pertanyaan tertutup serta empat pertanyaan terbuka terkait dengan keterlaksanaan pembelajaran matematika berbasis online. Analisis data dilakukan secara deskriptif dimana penelitian ini berupaya mendeskripsikan kesulitan belajar yang dialami siswa saat pembelajaran matematika berbasis online (e-learning) melalui pendeskripsian 
kata dan bukan angka (Moleong, 2017). Pada prosesnya, dilakukan pula wawancara dengan guru mata pelajaran untuk menguji keabsahan data penelitian, sehingga pengujian keabsahan data pada penelitian ini dilakukan melalui teknik triangulasi.

\section{HASIL DAN PEMBAHASAN}

Hasil analisis terhadap angket respon siswa mengenai keterlaksanaan pembelajaran matematika berbasis online (e-learning) diperlihatkan pada Tabel 1, berikut ini:

Tabel 1. Respon Siswa terhadap Keterlaksanaan Pembelajaran Matematika Berbasis Online (e-learning)

\begin{tabular}{|c|c|c|}
\hline \multicolumn{3}{|c|}{ Pertanyaan Tertutup } \\
\hline Pertanyaan & Ya & Tidak \\
\hline $\begin{array}{c}\text { Apakah sekolah kalian sedang } \\
\text { melaksanakan pembelajaran online } \\
\text { (e-learning)? }\end{array}$ & $100 \%$ & $0 \%$ \\
\hline $\begin{array}{l}\text { Apakah terdapat kendala atau } \\
\text { kesulitan selama kalian mengikuti } \\
\text { pembelajaran online pada } \\
\text { pembelajaran matematika? }\end{array}$ & $70,6 \%$ & $29,4 \%$ \\
\hline $\begin{array}{l}\text { Apakah kalian mudah memahami } \\
\text { penjelasan guru selama kegiatan } \\
\text { pembelajaran online? }\end{array}$ & $35,3 \%$ & $64,7 \%$ \\
\hline $\begin{array}{l}\text { Apakah kalian merasa lebih mudah } \\
\text { dalam mengungkapkan } \\
\text { pendapat/gagasan ketika } \\
\text { pembelajaran online dibandingkan } \\
\text { pembelajaran secara langsung? }\end{array}$ & $23,5 \%$ & $76,5 \%$ \\
\hline $\begin{array}{l}\text { Apakah kalian merasa lebih mudah } \\
\text { berdiskusi/berinteraksi dengan guru } \\
\text { ataupun teman kalian pada saat } \\
\text { pembelajaran online dibandingkan } \\
\text { pembelajaran secara langsung? }\end{array}$ & $11,8 \%$ & $88,2 \%$ \\
\hline $\begin{array}{c}\text { Apakah kalian dapat dengan } \\
\text { mudah mengungkapkan kembali } \\
\text { pemahaman yang kalian peroleh } \\
\text { baik secara lisan maupun tulisan } \\
\text { setelah pembelajaran online (jika } \\
\text { hal tersebut diminta)? }\end{array}$ & $41,2 \%$ & $58,8 \%$ \\
\hline $\begin{array}{c}\text { Apakah kalian lebih menyukai } \\
\text { pembelajaran online dibandingkan } \\
\text { dengan pembelajaran secara } \\
\text { langsung pada pembelajaran } \\
\text { matematika? }\end{array}$ & $11,8 \%$ & $88,2 \%$ \\
\hline
\end{tabular}




\begin{tabular}{|c|c|}
\hline \multicolumn{2}{|c|}{ Pertanyaan Terbuka } \\
\hline Pertanyaan & Jawaban \\
\hline $\begin{array}{l}\text { Media pembelajaran online apa } \\
\text { yang biasa digunakan dalam } \\
\text { pembelajaran matematika secara } \\
\text { online di sekolah? }\end{array}$ & $\begin{array}{c}\text { Google Classroom, Google Meet, Zoom } \\
\text { dan WhatsApp Group. }\end{array}$ \\
\hline $\begin{array}{l}\text { Kesulitan apa yang kalian hadapi } \\
\text { pada saat pembelajaran online } \\
\text { pada pembelajaran matematika? }\end{array}$ & $\begin{array}{l}\text { Jaringan internet yang tidak stabil, kuota } \\
\text { internet, penjelasan guru yang kurang } \\
\text { terdengar jelas, kurang memahami materi, } \\
\text { malas. }\end{array}$ \\
\hline $\begin{array}{l}\text { Tuliskan alasannya mengapa kalian } \\
\text { lebih menyukai salah satunya! }\end{array}$ & $\begin{array}{c}\text { Pembelajaran tatap muka secara } \\
\text { langsung: kurang memahami materi saat } \\
\text { pembelajaran online, bisa bertemu } \\
\text { dengan teman dan guru, lebih mudah } \\
\text { memahami materi, guru menjelasakan } \\
\text { secara jelas di sekolah, tidak suka sekolah } \\
\text { di rumah, tidak punya alat komunikasi, } \\
\text { mudah berdiskusi dan berinteraksi dengan } \\
\text { teman dan guru, pembelajaran online } \\
\text { tidak efektif. }\end{array}$ \\
\hline & $\begin{array}{l}\text { Pembelajaran online: lebih percaya diri, } \\
\text { menyukainya }\end{array}$ \\
\hline $\begin{array}{c}\text { Apa kesan yang kalian peroleh } \\
\text { selama pembelajaran online pada } \\
\text { pembelajaran matematika? }\end{array}$ & $\begin{array}{l}\text { Menyenangkan: } 47,06 \% \\
\text { Tidak menyenangkan: } 52,94 \%\end{array}$ \\
\hline
\end{tabular}

Berdasarkan Tebel 1, terlihat bahwa sebanyak $70,6 \%$ dari keseluruhan subjek penelitian menyatakan mengalami kendala dalam mengikutii pembelajaran matematika berbasis online (e-learning). Persentase yang diperoleh tersebut terbilang cukup besar dan melampaui setengahnya dari jumlah subjek penelitian. Hal tersebut menunjukan bahwa sebagian besar siswa mengalami hambatan atau kendala dalam mengikuti pembelajaran matematika berbasis online (e-leaning).

Kendala yang dihadapi siswa selama mengikuti pembelajaran matematika berbasis online (e-learning) diantaranya yaitu kendala teknis seperti Jaringan internet yang tidak stabil, kuota internet, serta penjelasan guru yang terdengar kurang jelas. Hal tersebut tidak dapat dipungkiri karena lokasi SMPN 1 Rawamerta tidak berada di pusat kota, sehingga hanya sedikit piihan provider penyedia layanan internet, itupun dengan kualitas yang kurang memadai, seingga belum mendukung pelaksanaan pembelajaran online. Berbeda dengan daerah perkotaan yang memiliki banyak provider layanan internet yang dapat mendukung pelaksanaan pembelajarn online (Hutauruk \& Sidabutar, 2020). 
Kendala berikutnya yaitu kendala personal atau kendala dari pribadi siswa sendiri. Kendala tersebut berupa kurangnya siswa memahami materi pembelajaran yang dapat disebabkan oleh beberapa faktor, seperti faktor internal yang berupa kurangnya persiapan siswa dalam mengikuti pembelajaran matematika berbasis online, serta faktor eksternal sebagai akibat dari kendala teknis yang berpengaruh pada pemahaman siswa. Adapun kendala personal lainnya berupa rasa malas dari diri siswa untuk mengikuti pembelajaran matematika berbasis online. Hal tersebut dapat diakibatkan oleh kurangnya kreativitas dalam mengemas pembelajaran yang menarik, sehingga mengakibatkan kurangnya minat siswa untuk mengikuti pembelajaran matematika berbasis online. Kendala personal tersebut secara umum dapat disebabkan dari adanya kendala teknis yang dialami selama proses pembelajaran.

Dari penjelasan sebelumnya dapat disimpulkan bahwa kendala yang dihadapi siswa dalam pembelajaran matematika berbasis online secara umum terbagi menjadi dua bagian yaitu kendala teknis dan kendala personal. Kendala tersebut mengakibatkan menurunnya performa siswa dalam pembelajaran matematika diantaranya yaitu kesulitan siswa dalam memahami penjelasan guru selama kegiatan pembelajaran. Hal tersebut terlihat dari data hasil analisis yang menunjukan sebanyak $64,7 \%$ atau lebih dari setengahnya menyatakan merasa kesulitan untuk memahami materi pembelajaran melalui pembelajaran online. Selain itu, $76,5 \%$ menyatakan mengalami kesulitan ketika hendak mengungkapkan pendapat atau gagasannya. Mereka juga merasa sulit dalam melakukan diskusi atau interaksi dengan guru ataupun temannya saat pembelajaran berlangsung. Hal tersebut mengakibatkan komunikasi dalam pembelajaran tidak berjalan dengan baik. Siswa juga merasa kesulitan ketika hendak mengungkapkan kembali pemahaman yang mereka dapatkan selama proses pembelajaran. Hal tersebut menunjukan belum utuhnya pemahaman yang siswa peroleh dari hasil pembelajaran matematika berbasis online. Semua pernyataan tersebut memberikan persentase di atas $50 \%$. Hal tersebut berarti bahwa dampak yang diberikan terbilang signifikan dalam mempengaruhi performa siswa dalam pembelajaran matematika berbasis online.

Dari sejumlah kendala yang dialami siswa selama pembelajaran online, serta dampak yang timbul sebagai akibat tidak optimalnya pembelajaran online tersebut mengakibatkan timbulnya persepsi negatif terhadap pembelajaran matematika berbasis online. Sebagian besar siswa menyatakan tidak menyukai pembelajaran online dan lebih menyukai jika pembelajaran matematika dilaksanakan secara langsung. Hal tersebut sesuai dengan hasil penelitian yang dilakukan oleh Megawanti, (2020) bahwa sebagian besar responden yang terdiri dari siswa dari jenjang SD hingga SMA menyatakan tidak senang dengan pembelajaran matematika secara online dan lebih memilih untuk melakukan pembelajaran dengan tatap muka secara langsung. Persepsi negatif tersebut didasari alasan bahwa siswa merasa pembelajaran secara langsung lebih efektif dibandingkan dengan pembelajaran berbasis online. Siswa bisa lebih memahami materi pembelajaran jika dijelaskan secara langsung. Mereka juga bisa berinteraksi serta 
melakukan diskusi dengan temannya ataupun guru dengan lebih leluasa. Disamping itu beberapa siswa juga mengalami kendala alat komunikasi untuk mengikuti pembelajaran online, sehingga tidak dapat mengikuti pembelajaran online secara efektif.

\section{KESIMPULAN DAN SARAN}

Dari uraian yang telah dijelaskan sebelumnya berkaitan dengan kendala yang dialami siswa dalam pembelajaran matematika berbasis online (e-learning), dapat disimpulkan bahwa secara umum kendala yang dialami oleh siswa terbagi menjadi dua bagian yaitu kendala teknis dan kendala personal. Kendala teknis dapat berupa Jaringan internet yang tidak stabil, kuota internet, serta penjelasan guru yang kurang terdengar jelas, sedangkan kendala personal yaitu kurangnya siswa dalam memahami materi pembelajaran, serta rasa malas untuk mengikuti pembelajaran matematika berbasis online.

Adapun saran yang dapat dipertimbangkan dari kesimpulan tersebut yaitu: (1) melakukan peninjauan kembali terkait dengan pelaksanaan pembelajaran matematika berbasis online (e-learning) di sekolah yang bersangkutan, (2) menggunakan media alternatif lain dalam pembelajaran matematika berbasis online seperti youtube untuk mempermudah siswa dalam memahami materi pembelajaran, (3) membuat konten pembelajaran matematika yang menarik sehingga dapat menumbuhkan motivasi siswa untuk mengikuti pembelajaran matematika berbasis online (e-learning).

\section{DAFTAR PUSTAKA}

Arcat, A. (2020). Pengaruh Penggunaan Video Pembelajaran Terhadap Hasil Belajar Komputer 1 Mahasiswa Pendidikan Matematika Semester II TP. 2019/2020 Universitas Pasir Pengaraian. Jurnal Absis: Jurnal Pendidikan Matematika Dan Matematika, 3(1), 250-256. https://doi.org/10.30606/absis.v3i1.496

Fatmawati, S. (2019). Efektivitas Forum Diskusi Pada E-Learning Berbasis Moodle Untuk Meningkatkan Partisipasi Belajar. Refleksi Edukatika: Jurnal IImiah Kependidikan, 9(2), 210-216. https://doi.org/10.24176/re.v9i2.3379

Hutauruk, A., \& Sidabutar, R. (2020). Kendala Pembelajaran Daring Selama Masa Pandemi di Kalangan Mahasiswa Pendidikan Matematika: Kajian Kualiatatif Deskriptif. Journal of Mathematics Education and Applied, 02 (01) , 45-51.

Lestari, W., Pratama, L. D., \& Jailani, J. (2018). Implementasi Pendekatan Saintifik Setting Kooperatif Tipe STAD Terhadap Motivasi Belajar Dan Prestasi Belajar Matematika. AKSIOMA: Jurnal Matematika Dan Pendidikan Matematika, 9(1), 29-39. https://doi.org/10.26877/aks.v9i1.2332

Megawanti, P., Megawati, E., \& Nurkhafifah, S. (2020). Persepsi Peserta Didik terhadap PJJ pada Masa Pandemi Covid-19. Jurnal Ilmiah Kependidikan, 7(2), 75-82. https://journal.Ippmunindra.ac.id/index.php/Faktor/article/view/6411/3160

Moleong, L. . (2017). Metode Penelitian Kualitatif. PT. Remaja Rosdakarya. 
Ningsih, R., \& Nurrahmah, A. (2016). Pengaruh Kemandirian Belajar dan Perhatian Orang Tua Terhadap Prestasi Belajar Matematika. Formatif: Jurnal Ilmiah Pendidikan MIPA, 6(1), 73-84. https://doi.org/10.30998/formatif.v6il.754

Rohmah, L. (2011). Konsep E-Learning Dan Aplikasinya Pada Lembaga Pendidikan Islam. An Nur, 1 (1), 255-270. https://doi.org/10.24042/atjpi.v8i1.2099

Ulfa, M. (2019). Strategi Preview, Question, Read, Reflect, Recite, Review (PQ4R) Pada Pemahaman Konsep Matematika. Mathema Journal, 1 (1), 48-55.

Utami, Y. P., \& Cahyono, D. A. D. (2020). Study At Home: Analisis Kesulitan Belajar Matematika Pada Proses Pembelajaran Daring. Jurnal IImiah Matematika Realistik, 1 (1), 20-26. https://doi.org/10.33365/ji-mr.v1i1.252

Warmi, A., Adirakasiwi, A. G., \& Santoso, E. (2020). Motivasi dan Kemandirian Belajar Siswa Pada Mata Pelajaran Matematika di Masa Pandemi Covid-19 (Studi pada Siswa Kelas VII SMP Negeri 3 Karawang Tahun Pelajaran 2019-2020). Jurnal Education and Development, 8(3), 197-202. 